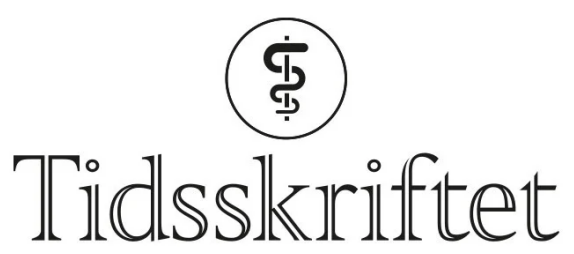

DEN NORSKE LEGEFORENING

\title{
La de små barn komme til meg
}

FRA REDAKTØREN

\section{ØYVIND STOPLE SIVERTSEN}

oyvind.stople.sivertsen@tidsskriftet.no

Øyvind Stople Sivertsen er allmennlege i spesialisering og medisinsk redaktør i Tidsskriftet.

\section{Fastleger bør beholde sin sentrale rolle i svangerskapsoppfølgingen.}

Foto: Sturlason

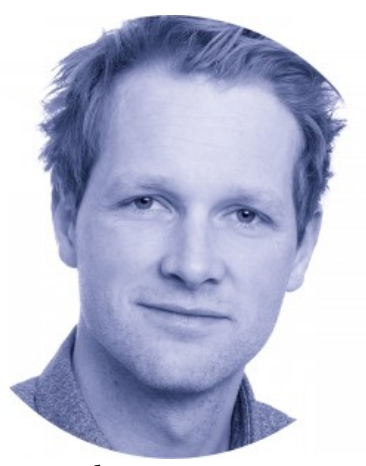

Årlig fødes om lag 55000 barn i Norge (1). I et normalt svangerskap tilbys mor åtte faste kontroller, og kvinnen kan velge om hun vil oppsøke lege eller jordmor. Med en fastlegeordning under press er det kanskje faux pas å snakke om alt man vil beholde. Ikke minst kan det gjelde disse mer enn 440 ooo potensielle timeavtalene.

God svangerskaps- og barselomsorg er et finvevd samspill mellom leger, jordmødre og helsesykepleiere. Det gjør at det som oftest går bra med norske gravide og barn. Norge er blant landene i verden med lavest mødredødelighet i svangerskapet (므), og også lavest komplikasjons- og dødelighetsrate både blant barn som fødes for tidlig og barn som fødes til termin (3,4). Tall fra Medisinsk fødselsregister viser at over to tredeler av alle fødsler hos førstegangsfødende forløper uten større inngrep eller komplikasjoner, for flergangsfødende er andelen inntil ni av ti (5).

Hvert svangerskap, hvert barn rommer imidlertid så mye mer enn tall og landsgjennomsnitt. De nye familiene står foran forventning, bekymring, frykt, angst, lettelse og iblant sorg. Følelsene varierer fra den dypeste fortvilelse til ubetinget lykke. Det finnes endeløse måter å gå seg vill i velmente råd i svangerskapet, og minst like mange etter forløsning. De aller fleste vil vel for sine barn. Men hva er best, og hvor skal man gå? Er det jordmor eller lege som er den riktige å konsultere? 
I mange kommuner har leger og jordmødre et godt og effektivt samarbeid. Oppfølgingen av gravide er helhetlig, og hver faggruppe får brukt sine styrker. Men i sommer ble svangerskapsoppfølgingen til en slags konkurranse. I august la Jordmorforbundet ut en video på sine Facebook-sider, der det ble hevdet at det går bedre med både mor og barn dersom de følges av jordmor i svangerskapet. Det skapte naturligvis reaksjoner (므). Budskapet var at alle burde gå til jordmor i svangerskapet, som ble angitt å være eksperter på kvinners helse. Dessverre var ikke budskapet bare unyansert, det var feil.

«Svangerskapsomsorg er for viktig til å bli gjort til en dragkamp mellom ulike faggrupper»

Kunnskapsgrunnlaget som ble brukt, en Cochrane-rapport fra 2015, er senere blitt oppdatert, og konklusjonene er endret (7.). Gruppene som ble sammenlignet, var kvinner som ble fulgt av jordmor fra første kontroll og gjennom svangerskapet, helt til fødsel, av samme jordmor - såkalt jordmorstyrt omsorg. Dette er ikke sammenlignbart med norske forhold, der de fleste møter en helt annen jordmor på sykehuset enn den de er blitt fulgt opp av i svangerskapet. Suksesskriteriet er således antakelig ikke jordmoren per se, men at man får tilbud om kontinuitet i omsorgen og oppfølgingen.

I juni forfattet lederne av Norsk sykepleierforbund og Jordmorforbundet et debattinnlegg hvor de gikk langt i å hevde at det er økonomien som er styrende for fastlegers interesse for gravide ( $\underline{8}$ ). De $\emptyset$ nsket seg samtidig både sykmeldingsrett og henvisningsadgang. Der det kan være lett å finne gode argumenter for sistnevnte, virker ønsket om å kunne sykmelde mindre gjennomtenkt. Vurdering av sykmeldingsgrad krever kunnskap om tilretteleggingsmuligheter, trygdemedisin, attestarbeid og andre sykdommer enn graviditeten induserer. Jeg tror mange fastleger er med meg når jeg postulerer «tilgi dem, for de vet ikke hva de gjør» om ønsket om sykmeldingsrett.

Flere og flere gravide kvinner har kroniske sykdommer, som diabetes, astma/allergi, stoffskiftesykdom, hjerte- og karsykdom, arvelige sykdommer, psykisk sykdom eller misbruksproblematikk (9.). Slike tilstander medfører behov for legevurdering under og etter svangerskapet. Det er en viktig fastlegeoppgave, og gir kvinnen trygghet og kontinuitet.

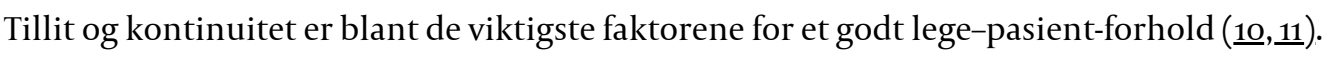
Dersom vi fjerner svangerskap og barselperiode fra dette forholdet, mister både pasienter og leger mer enn man ved første øyekast kanskje tror. Svangerskapet er en spesiell og sårbar periode i en kvinnes liv. Det bør være en selvfølge at fastlegen både er interessert, oppdatert og engasjert i denne perioden.

Svangerskapsomsorg er for viktig til å bli gjort til en dragkamp mellom ulike faggrupper. Aller best blir den antakelig når leger og jordmødre utfører den i fellesskap, med gode retningslinjer om hvem som bør gjøre hva - og når. Ikke hvem som skal gjøre alt.

\section{LITTERATUR}

1. Statistisk sentralbyrå. Fødte i 2019. https://www.ssb.no/fodte/ Lest 27.8.2020.

2. World Health Organization. Maternal mortality 2000-2017.

https://www.who.int/reproductivehealth/publications/maternal-mortality-200o-2017/en/ Lest 27.8.2020.

3. Born too soon: The global action report on preterm birth. Geneve: World Health Organization, 2012: 29. https://www.who.int/maternal_child_adolescent/documents/born_too_soon/en/ Lest 27.8.2020.

4. FN. Sustainable developmental goals. Infant mortality rate.

https://unstats.un.org/sdgs/indicators/database/?indicator=3.2.1 Lest 27.8.2020. 
5. Folkehelseinstituttet. Medisinsk fødselsregister. Komplikasjoner under fødselen. http://statistikkbank.fhi.no/mfr/ Lest 27.8.2020.

6. Tømmerbakke SG. Reagerer på jordmorkampanje. Dagens Medisin 7.8.2020. https://www.dagensmedisin.no/artikler/2020/o8/o7/reagerer-pa-jordmorkampanje--feilinformasjon/ Lest 25.8.2020.

7. Sandall J, Soltani H, Gates S et al. Midwife-led continuity models versus other models of care for childbearing women. Cochrane Database Syst Rev 2016; 4: CDoo4667. [PubMed][CrossRef]

8. Schjelderup HC, Pettersen K, Dalseg I et al. Jordmødre bør få mer ansvar for kvinners helse. Sykepleien. https://sykepleien.no/meninger/innspill/2020/o6/jordmodre-bor-fa-mer-ansvar-kvinnershelse?fbclid=IwAR1MZ_7r_8CI1s1GHxEx2FLXppLOg--uEoJK9Fx88AE8AY6A1rIYmuH31JA Lest 25.8.2020.

9. Folkehelseinstituttet. Medisinsk fødselsregister. http://statistikkbank.fhi.no/mfr/ Lest 27.8.2020.

10. Tarrant C, Dixon-Woods M, Colman AM et al. Continuity and trust in primary care: a qualitative study informed by game theory. Ann Fam Med 2010; 8: 440-6. [PubMed][CrossRef]

11. Cabana MD, Jee SH. Does continuity of care improve patient outcomes? J Fam Pract 2004; 53: 9748o. [PubMed]

Publisert: 7. september 2020. Tidsskr Nor Legeforen. DOI: 10.4045/tidsskr.20.0682

(C) Tidsskrift for Den norske legeforening 2023. Lastet ned fra tidsskriftet.no 26. april 2023. 